\title{
A női lakosság szervezett méhnyak- és emlőszűrésen való részvétele Nyíregyházán
}

\author{
Participation of the female population in an organised cervical and \\ breast cancer screening programme in Nyíregyháza
}

Szerzők: $\quad G y u l a i$ Anikóa $\varangle$, Sárváry Attila ${ }^{b}$, Rákóczi Ildikóa ${ }^{a}$, Takács Péter ${ }^{c}$, Jávorné Erdei Renáta a: Debreceni Egyetem, Egészségügyi Kar, Egészségtudományi Intézet, Védőnői Módszertani és Népegészségtani Tanszék, b: Debreceni Egyetem, Egészségügyi Kar, Egészségtudományi Intézet, Ápolástudományi Tanszék, c: Debreceni Egyetem, Egészségügyi Kar, Egészségtudományi Intézet, Egészségügyi Informatikai Tanszék

Beküldve: $\quad$ 2019. 09. 16.

doi: $\quad$ 10.24365/ef.v60i5.520

\begin{abstract}
Összefoglaló:
Bevezetés: Az emlő- és a méhnyakrák jelentős mértékben járul hozzá a nők rosszindulatú daganatos halálozásához világszerte és Magyarországon is. A szervezett emlő- és méhnyakszűrés bevezetésére népegészségügyi program keretében került sor Magyarországon. Célunk volt feltárni a szűrési programok célcsoportjába tartozó nyíregyházi nők emlő- és méhnyakszürésen való részvételét, összehasonlítva a magyarországi és az európai adatokkal, továbbá összefüggést kerestünk az átszúrtséget meghatározó demográfiai és társadalmi-gazdasági tényezők között.
\end{abstract}

Módszertan: A „Nyíregyháza város életminősége - Háztartáspanel” vizsgálat keretében 2018ban megvalósult egészségfelmérés adataiból az emlő- és méhnyakszűrésen való részvétel gyakoriságát elemeztük.

Eredmények: A válaszadók 77\%-a (95\% MT: 70-83) vett részt méhnyakszürésen az Egészségügyi Világszervezet által ajánlott hároméves időintervallumon belül. A szürésen három éven belül részt vettek átlagéletkora több, mint 7 évvel (két mintás t próba $p<0,001$ ) fiatalabb volt, mint a szürést elkerülóké (44,5 év; SD: 1,07 vs. 51,8 év; SD: 2,09). Megállapítottuk, hogy a magasabb jövedelmi kategóriába eső háztartásokban élő és gazdaságilag aktívak körében szignifikánsan magasabb a méhnyakszürésen való részvétel. Az emlőszűrésen a nők $80 \%$-a vett részt az adatfelvételt megelőző két éven belül. A mammográfián való részvétel oka leggyakrabban (57\%; 95\% MT: 46-68) a szervezett szúrésre történő meghívás volt, az esetek egyharmadában orvosi javaslatra történt a vizsgálat, és 11\%-ban egyéb okból. A mammográfián két éven belül részt vettek átlagéletkora 4 évvel fiatalabb volt, mint azoké, akik két éven túl, vagy soha nem vették igénybe a mammográfiás vizsgálatot ( 57 év; SD: 0,8 vs. 53 év; SD: 1,8). Szignifikánsan magasabb átszűrtséggel rendelkeztek a legalább középfokú végzettséggel rendelkezők, mint a legfeljebb alapfokú végzettségűek csoportja.

Következtetések: A nyíregyházi nők emlö- és méhnyakszürésen való részvétele nem alacsony, azonban a szervezett szúrőprogramokkal nem sikerült az alacsonyabb társadalmi-gazdasági státuszú, idősebb nőket kellő mértékben bevonni.

Kulcsszavak: részvétel; méhnyakszúrés; emlőszúrés; Nyíregyháza

Summary:

Introduction: Breast and cervical cancer is a major contributor to deaths caused by cancer among women worldwide and in Hungary. The organized breast and cervical cancer screening 
programs were implemented in the framework of a public health programme in Hungary. Our aim was to explore the participation in breast and cervical cancer screening of women in the target group of screening programs in Nyíregyháza, comparing it with Hungarian and European data, and to look for the relationship between the demographic and socio-economic factors determining screening participation.

Methods: We analysed the frequency of participating in breast and cervical screening from the study "The quality of life in Nyíregyháza city Household panel" (2018).

Results: $77 \%$ of respondents (95\% Cl: $70-83$ ) underwent cervical screening within the threeyear interval recommended by the World Health Organization. The mean age of those who participated in the screening within three years was more than 7 years (two-sample t test $p<0.001$ ) younger than those who did not participate (44.5 years (SD: 1.07$)$ vs. 51.8 years (SD: 2.09)). We found that participation in cervical screening is significantly higher among those, who live in higher income households and are economically active. $80 \%$ of women underwent breast screening in the two years prior to data collection. The most common reason for participating in mammography $(57 \%(95 \% \mathrm{Cl}$ : 46-68)) was the invitation to an organized screening, in one third of cases for medical advice and in $11 \%$ for other reasons. Participants in mammography within two years had an average age of 4 years younger than those who had received mammography for more than two years before or never (57 years (SD: 0.8) vs. 53 years (SD: 1.8)). Those with at least upper secondary education had significantly higher screening rates than those with at most lower secondary education.

Conclusions: The participation of women in Nyíregyháza in breast and cervical screening is not low, but organized screening programs have failed to adequately involve older women of lower socio-economic status.

Keywords: participation; cervical cancer screening; breast cancer screening; Nyíregyháza

\section{BEVEZETÉS}

A rosszindulatú daganatos betegségek előfordulási gyakorisága világszerte növekszik, a fejlett országokban a vezető halálokok közé tartoznak és a fejlődő országokban is egyre jelentősebb részét teszik ki a betegségterheknek. Az Egészségügyi Világszervezet Nemzetközi Rákkutatási Ügynökségének (International Agency for Research on Cancer, IARC) a Global Burden of Cancer Study (GLOBOCAN) becslései szerint 2018-ban a Földön 18078957 új rosszindulatú daganatos megbetegedést diagnosztizáltak, ebből 8622539 eset a nőknél következett be. ${ }^{1}$ Magyarországon a daganatos megbetegedések különlegesen súlyos népegészségügyi problémát jelentenek, mind az egészségügyi ellátórendszer, mind pedig a társadalom egésze számára. Hazánkban a daganatos betegségek miatti halálozás a vezető halálokok közé tartozik, 2016-ban az összes korcsoportban a második, a 0-64 éves korcsoportban pedig az első helyen szerepelt mindkét nemben. ${ }^{2} \mathrm{~A}$ nők körében a leggyakoribb daganatos megbetegedés az emlőrák, a méhnyakrák az 5 . helyen szerepelt, míg a női daganatos halálozás sorrendjében az emlőrák a második, a méhnyakrák szintén az 5. helyen állt Magyarországon. 2,3 A 25-64 éves magyar nők daganatos betegségek miatti halálozása 2011-ben közel kétszer, az emlőrák okozta halálozása 1,2-szer, a méhnyakrák okozta halálozása 3,1-szer volt magasabb az Európai Unióhoz 2004 előtt csatlakozott (EU15) tagországokéhoz képest. ${ }^{3}$ A Nemzeti Rákregiszter adatai szerint 2016-ban Magyarországon összesen 54358 nő esetében diagnosztizáltak rosszindulatú daganatos megbetegedést, ebből 8660 esetben emlő-, és 1186 esetben méhnyakrákot. ${ }^{4}$ A Központi Statisztikai Hivatal halálozási adatbázisának adatai alapján ebben az évben 396 nő halálát okozta a méhnyakrák, ebből 41 fó élt Szabolcs-Szatmár-Bereg megyében, és 3 fő Nyíregyházán. Emlőrák miatt 2223 nő halálozott el, ebből 84 fő a megyében és 30 fő Nyíregyházán. ${ }^{5}$

A méhnyakrák kiemelt népegészségügyi jelentőségét az adja, hogy az elkerülhető halálokok közé tartozik, vagyis olyan halálok, amely a szükséges egészségügyi ellátás időben történő igénybevételével megelőzhető. ${ }^{6} \mathrm{Az}$ elkerülhető halálozás muta- 
tóját az ellátórendszer minőségének jellemzésére vezették be, mértékét befolyásolja egyrészt az adott betegség esetében szükséges egészségügyi ellátás hozzáférhetősége, másrészt a lakosság igénybevételi hajlandósága. ${ }^{7}$ A méhnyakrák legfontosabb oki tényezője a magas kockázatú humán papillomavírussal (HPV) történő tartós fertőzés. ${ }^{8}$ Jól szervezett szűréssel, valamint megfelelő kezeléssel a méhnyakrák nagy részének a kialakulása megelőzhető lenne. ${ }^{9,10}$ Ezért a betegség előfordulásának és halálozásának a tendenciái tükrözik az adott népesség körében elérhető szűrővizsgálat minőségét, a lakosság részvételét (a szűrővizsgálat lefedettségét), valamint a kockázati tényezőknek való kitettség változásait. ${ }^{11,12,13}$

Az emlőrák fejlődésmenete szintén ismert, az általa okozott halálozás csökkentésére a szervezett emlőszúrésnek bizonyított hatása van, melyet randomizált, kontrollált vizsgálatokkal igazoltak. ${ }^{14,15}$

Hazánkban mindkét betegség megelőzése érdekében létezik a népegészségügyi program keretében szervezett szúrőprogram, amely megfelel a nemzetközi ajánlásoknak és kritériumoknak. ${ }^{16,17,18} \mathrm{Az}$ emlőrák megelőzésére a 45-65 év közötti nők kétévenként végzett emlőszưrése lágyrész röntgenvizsgálattal (mammográfiával) történik, a méhnyakrák megelőzésére a 25-65 év közötti nők negatív szűrővizsgálatát követően 3 évenként megismételt citológiai vizsgálatot is alkalmazó méhnyakszűrés elérhető. ${ }^{17,18}$

A szervezett szűrések csak meghatározott részvételi arány mellett érik el a céljukat, ezért a hatékonyságuk kulcseleme a lakosság részvétele (compliance). A Nyíregyháza város életminősége Háztartáspanel kutatás keretében 2018-ban megvalósult egészségfelmérés (Egészségpanel) adataiból jelen cikkükben a nyíregyházi nők népegészségügyi célú méhnyakés emlőszűrésen való részvételét, átszűrtségét vizsgáltuk. Célunk volt feltárni a nyíregyházi nők emlő- és méhnyakszűrésen való részvételi gyakoriságát, összehasonlítva a magyarországi és az európai adatokkal, továbbá összefüggést kerestünk az átszűrtséget meghatározó demográfiai és társadalmi-gazdasági tényezők között. A felmérés eredményei hozzájárulhatnak azon lakossági csoportok azonosításához, akik ritkábban, vagy kisebb eséllyel veszik igénybe a szürővizsgálatokat.

\section{MÓDSZERTAN}

A Nyíregyháza város életminősége Háztartáspanel kutatás 2008 óta öt hullámban, két-, illetve háromévente mérte fel a városlakók életminőségét. A mintaválasztás módszerét és általános jellemzőinek leírását jelen különszám módszertani bevezetése tárgyalja.' A 2018-as felmérés két szakaszban történt meg. Az első szakaszban, 2017 őszén 541 háztartást értek el, a második szakaszban, 2018 tavaszán pedig 391-et, melyből 386-ot vontak be az elemzésbe. A Panelkutatás Egészségpanel része az első felmérési szakaszban egyetlen kérdéssel érintette az egészségre, egészségügyre vonatkozó témakört, a második szakasz pedig az egészségi állapot felmérésére koncentrált, melyben a mentális és fizikai egészség, valamint a rizikómagatartás vizsgálata mellett helyet kapott az önminősített egészégi állapot felmérése is. A vizsgálat során a népegészségügyi célú méhnyak- és emlőszűrésen való részvétel elemzéséhez az Európai Lakossági Egészségfelmérés 2009-es kérdőívének ide vonatkozó kérdéseit használtuk. Az emlőszűrés esetén kérdeztük, hogy részt vett-e valaha életében emlőröntgen vagy más néven, mammográfiás vizsgálaton, ha igen, akkor mikor volt az utolsó vizsgálat időpontja (az elmúlt 12 hónapban/egy éven túl, de két éven belül/több, mint két éve, de 3 éven belül/ 3 évnél régebben/soha). Rákérdeztünk, hogy milyen okból történt a vizsgálat (pl. orvosi javaslatra/ szűrési meghívásra/egyéb ok miatt). A méhnyakszűrésre vonatkozó kérdés az volt, hogy „Mikor vettek Öntől utoljára kenetet citológiai (méhnyakhámsejt) vizsgálatra, méhnyakrák szürése céljából?" (A válaszok: az elmúlt 12 hónapban/egy éven túl, de két éven belül/több, mint két éve, de 3 éven belül/ 3 évnél régebben/soha). Itt is rákérdeztünk a vizsgálat okára ( $p l$. észlelt rendellenesség miatt/rutinvizsgálat során/országos szűrési meghívásra/egyéb ok miatt). Az elemzés során a népegészségügyi céloknak és ajánlásoknak megfelelően, a célcsoportot a mammográfiára vonatkozóan a 45-65 éves nők, a méhnyakszúrés esetében pedig a 25-65 éves nőkre szűkítettük. A lakossági részvételt (lefedettséget) a mammográfia vonatkozásában két éven belül, a méhnyakszűrésen való részvételt pedig három éven belül vizsgáltuk. A statisztikai elemzést

\footnotetext{
¡Takács Péter, Fábián Gergely, Jávorné Erdei Renáta: A 2018-as Nyíregyháza város életminősége Háztartáspanel kutatás általános és EgészségPane szakaszainak mintavételi jellemzői. doi: 10.24365/ef.v60i5.523
} 
az SPSS (Version 22.0) programcsomag felhasználásával végeztük el. ${ }^{19} \mathrm{Az}$ adatfeldolgozás során a deskriptív epidemiológia módszereit alkalmaztuk, a gyakorisági értékek esetén 95\%-os megbízhatósági tartományt (MT) vettünk figyelembe. A kategorikus változópárok közötti összefüggések erősségének vizsgálatára Pearson-féle khí-négyzet próbát használtunk, a folytonos változók esetén pedig két mintás t-próbát alkalmaztunk. Az eredményt $p<0,05$ esetén tekintettük statisztikailag szignifikánsnak.

\section{EREDMÉNYEK}

\section{Méhnyakszűrés}

Mint ahogy a módszertani részben is említettük, a vizsgálatban résztvevő nyíregyházi nők méhnyakszürésen való részvételét a 25-65 éves korosztályban vizsgáltuk. Ebbe a csoportba 157 fő tartozott, átlagéletkoruk 46,2 év (SD: 12,2) volt. Iskolai végzettségüket tekintve 6,7\%-uk (95\% MT: 3,311,3) alapfokú, 54,7\%-uk (95\% MT: 46,7-63,3) középfokú, és 38,7\%-uk (95\% MT: 30,7-46,7) felsőfokú végzettséggel rendelkezett. Egy fő roma nemzetiségű válaszadó kivételével mindenki magyar nemzetiségűnek vallotta magát.

Az eredmények alapján megállapítottuk, hogy a válaszadók 77\%-a (95\% MT: 70-83) vett részt méhnyakszúrésen az Egészségügyi Világszervet által ajánlott hároméves időintervallumon belül. Ezen belül a felmérést megelőző egy évben a válaszadók 42\%-a (95\% MT: 36-52), és további 35\%-uk egy éven túl, de három éven belül vette igénybe a vizsgálatot. [1. ábra]

A három éven belül szürt nők kétharmada (74\%; 95\% MT: 66-81) saját kezdeményezésre, vagyis „rutinvizsgálat” miatt vett részt, míg a szervezett szűrőprogram keretében kiküldött meghívólevél hatására csupán a résztvevő nők 12,5\%-a (95\% MT: 7-18) vette igénybe az ellátást.

A szűrésen három éven belül részt vettek átlagéletkora több, mint 7 évvel (két mintás t-próba $p<0,001$ ) fiatalabb volt, mint a szúrést elkerülőké (44,5 év; SD: 1,07, ellentétben 51,8 év; SD: 2,09). A szürésen való részvétel és az iskolai végzettség közötti összefüggés vizsgálata során azt tapasztaltuk, hogy a felsőfokú iskolai végzettségúek hároméves lefedettsége volt a legmagasabb (85\%), a középfokú végzettségúek körében 73\%-os, az alapfokú végzettséggel rendelkezők esetében pedig 60\%-os volt az átszürtség. Az eltérés nem mutatott statisztikailag megbízható mértékú különbséget ( $\chi 2$-próba: $p>0,05)$.

Megállapítottuk, hogy a magasabb jövedelmi kategóriába eső háztartásokban élő és gazdaságilag aktívak körében szignifikánsan magasabb a méhnyakszűrésen való részvételi hajlandóság.

\section{[1. táblázat]}

1. ábra: A női lakosság méhnyakszürésen való részvétele Nyíregyházán (n=157) (\%)

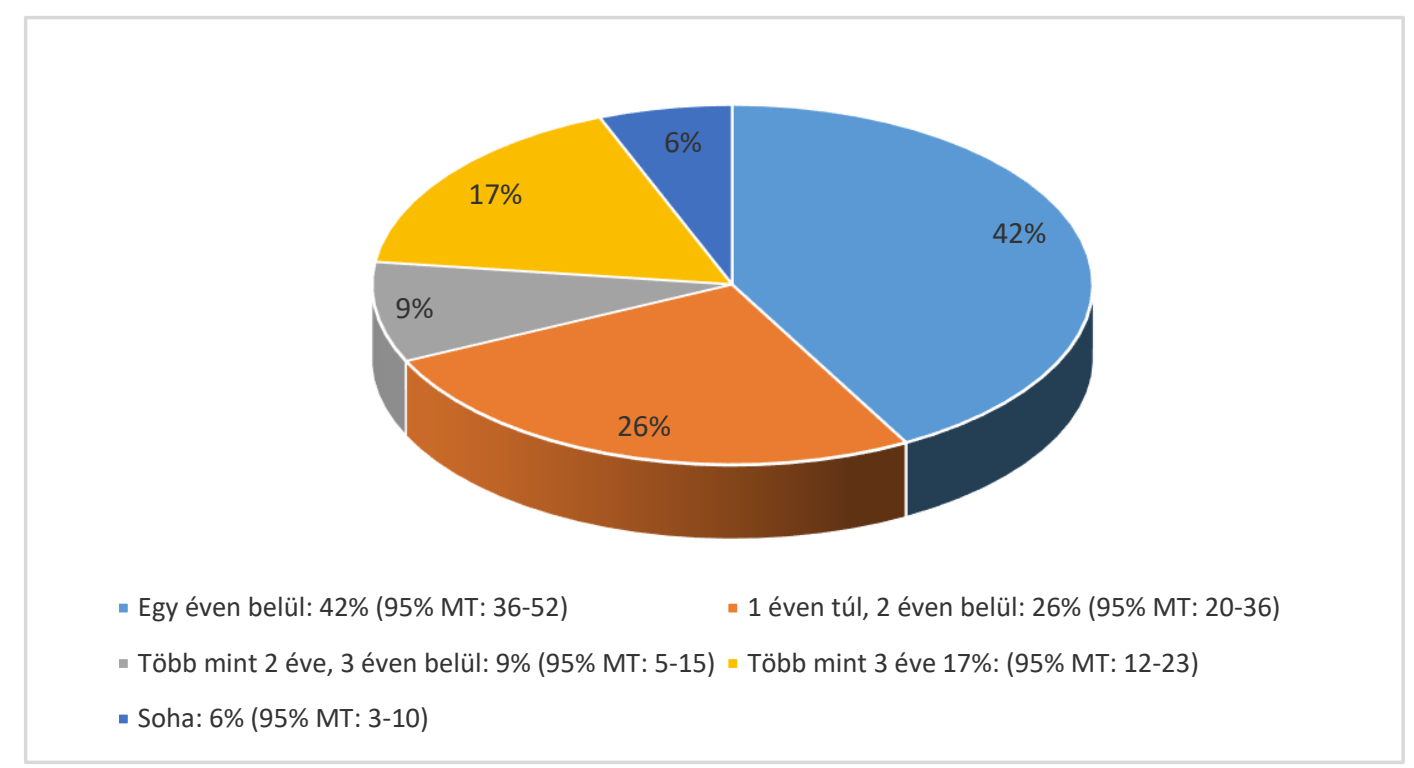

Forrás: Saját szerkesztés 
A mintában szereplő nyíregyházi nők iskolai végzettség szerinti átszűrtségét összehasonlítottuk a magyarországi, valamint az Európai Unió 28 országának átlagára vonatkozó adatokkal. Az összehasonlításhoz az Európai Unió Statisztikai Hivatala (EUROSTAT) 2014-es Európai Lakossági Egészségfelmérésének (European Health Interview Survey,
EHIS) adatbázisából kérdeztük le az iskolai végzettség szerinti adatokat. ${ }^{20}$ Megállapítható, hogy a végzettség tekintetében a felsőfokú végzettségűek, a vizsgált területek közül pedig minden kategóriában és az átlagos átszúrtséget tekintve is a Nyíregyháza Megyei Jogú Város női lakossága rendelkezett a legmagasabb átszűrtségi adatokkal. [2. ábra]

1. táblázat: A méhnyakszürésen három éven belül résztvevő és a részt nem vevő 25-65 éves korú nők demográfiai és szociális jellemzői Nyíregyházán (n=157)

\begin{tabular}{|c|c|c|c|}
\hline Jellemzők & $\begin{array}{l}\text { Szűrésen három éven } \\
\text { belül résztvevők }\end{array}$ & $\begin{array}{l}\text { Szűrésen három éven } \\
\text { belül nem résztvevők }\end{array}$ & p-érték \\
\hline Életkor (átlag) (SD) & $44,5(1,07)$ & $51,8(2,09)$ & $\begin{array}{l}\text { Két mintás t-próba } \\
\qquad \mathrm{p}<0,001^{*}\end{array}$ \\
\hline $\begin{array}{l}\text { Iskolai végzettség } \\
\text { Alapfokú végzettség } \\
\text { Középfokú végzettség } \\
\text { Felsőfokú végzettség }\end{array}$ & $\begin{array}{l}60 \% \\
73 \% \\
85 \%\end{array}$ & $\begin{array}{l}40 \% \\
27 \% \\
15 \%\end{array}$ & $\begin{array}{l}\chi 2 \text { próba } \\
p>0,05\end{array}$ \\
\hline Foglalkoztatottság (\%) & $85 \%$ & $54 \%$ & $\begin{array}{l}\chi 2 \text { próba } \\
p<0,001^{*}\end{array}$ \\
\hline $\begin{array}{l}\text { Háztartások nettó jövedelme (át- } \\
\text { lag) (SD) (forint) }\end{array}$ & 297444 (136 195) & 243200 (144 397) & $\begin{array}{l}\text { Két mintás t-próba } \\
\qquad p>0,05\end{array}$ \\
\hline $\begin{array}{l}\text { Háztartások nettó jövedelme } \\
100 \text { ezer Ft/hó alatt } \\
\text { 101-200 ezer Ft/hó } \\
\text { 201-300 ezer Ft/hó } \\
300 \text { ezer Ft/hó fölött }\end{array}$ & $\begin{array}{l}53 \% \\
76 \% \\
90 \% \\
78 \%\end{array}$ & $\begin{array}{l}47 \% \\
24 \% \\
10 \% \\
22 \%\end{array}$ & $\begin{array}{l}x 2 \text { próba } \\
p=0,023^{*}\end{array}$ \\
\hline
\end{tabular}

Forrás: Saját szerkesztés

2. ábra: A célcsoport három éven belüli részvétele a méhnyakszürésen Nyíregyházán, Magyarországon és az Európai Unió 28 országában iskolai végzettség szerint (\%)

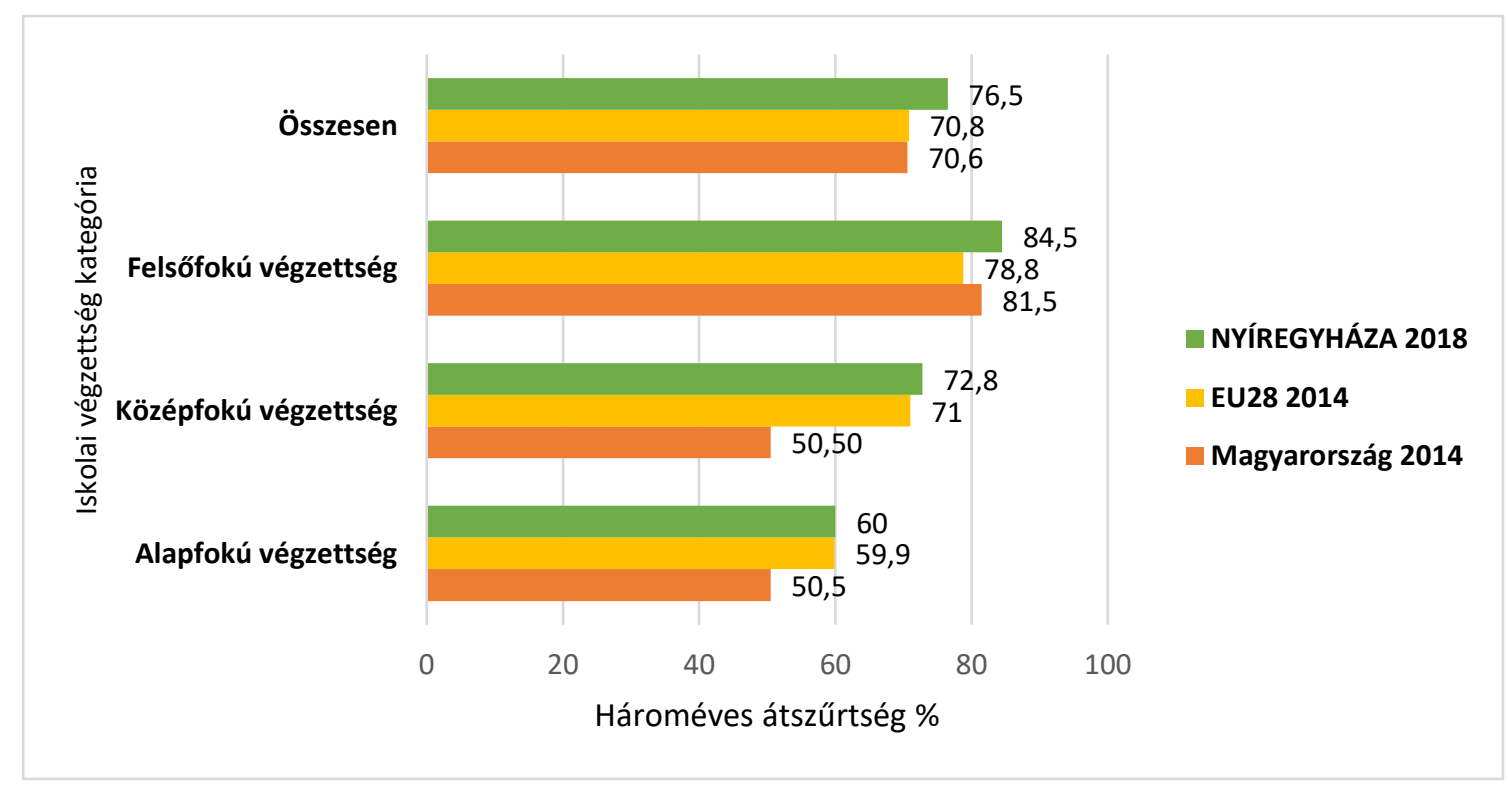

Forrás: Saját szerkesztés 


\section{Emlőszürés}

Az emlőszűrésen való részvételt a 45-65 éves korú nők (84 fő) körében elemeztük, az átlagéletkor 55,8 év (SD: 6,3 év) volt. Az elemzés során azokat tekintettük szűrésen részt vetteknek, akik az adatfelvételt megelőző két éven belül voltak emlőszűrő vizsgálaton, tehát a célcsoport kétéves átszűrtségét elemeztük, a népegészségügyi ajánlásnak megfelelően.

A válaszadók 6\%-ának kivételével minden nő részt vett már valamikor élete során legalább egy alkalommal emlőszűrő vizsgálaton. Az átszűrtséget tekintve is igen kedvezőek az adatok, a nők $80 \%$-a nyilatkozta azt, hogy részt vett mammográfián az adatfelvételt megelőző két éven belül. [3. ábra]

A mammográfián való részvétel oka leggyakrabban (57\%; 95\% MT: 46-68) a szervezett szűrésre történő meghívás volt, az esetek egyharmadában orvosi javaslatra történt a vizsgálat, és 11\%-ban egyéb okból. A szürésen két éven belül részt vettek átlagéletkora
4 évvel fiatalabb volt, mint azoké, akik két éven túl, vagy soha nem vették igénybe a mammográfiás vizsgálatot (57 év; SD: 0,8, ellentétben 53 év; SD: 1,8). Szignifikánsan magasabb átszűrtséggel rendelkeztek a legalább középfokú végzettséggel rendelkezők, mint a legfeljebb alapfokú végzettségűek csoportja. A többi vizsgált háttérváltozó, ezen belül a háztartások nettó összjövedelme, valamint a nők foglalkoztatottsági státuszát tekintve nem találtunk statisztikailag megbízható mértékű eltérést a szűrésen résztvevők és a nem résztvevők csoportja között. [2. táblázat]

A mintában szereplő nyíregyházi nők iskolai végzettség szerinti átszűrtségét az emlőszűrés esetében is összehasonlítottuk a magyarországi, valamint az Európai Unió 28 országának átlagára vonatkozó adatokkal. Megállapítható, hogy a végzettség tekintetében az alapfokú végzettségúek részvételi hajlandósága mind a magyarországi, mind pedig az Európai Unió 28 országára vonatkozó átlagértéknél alacsonyabb volt a nyíregyházi nők mintáján. [4. ábra]

3. ábra: A női lakosság emlőszürésen való részvétele Nyíregyházán (n=84) (\%)

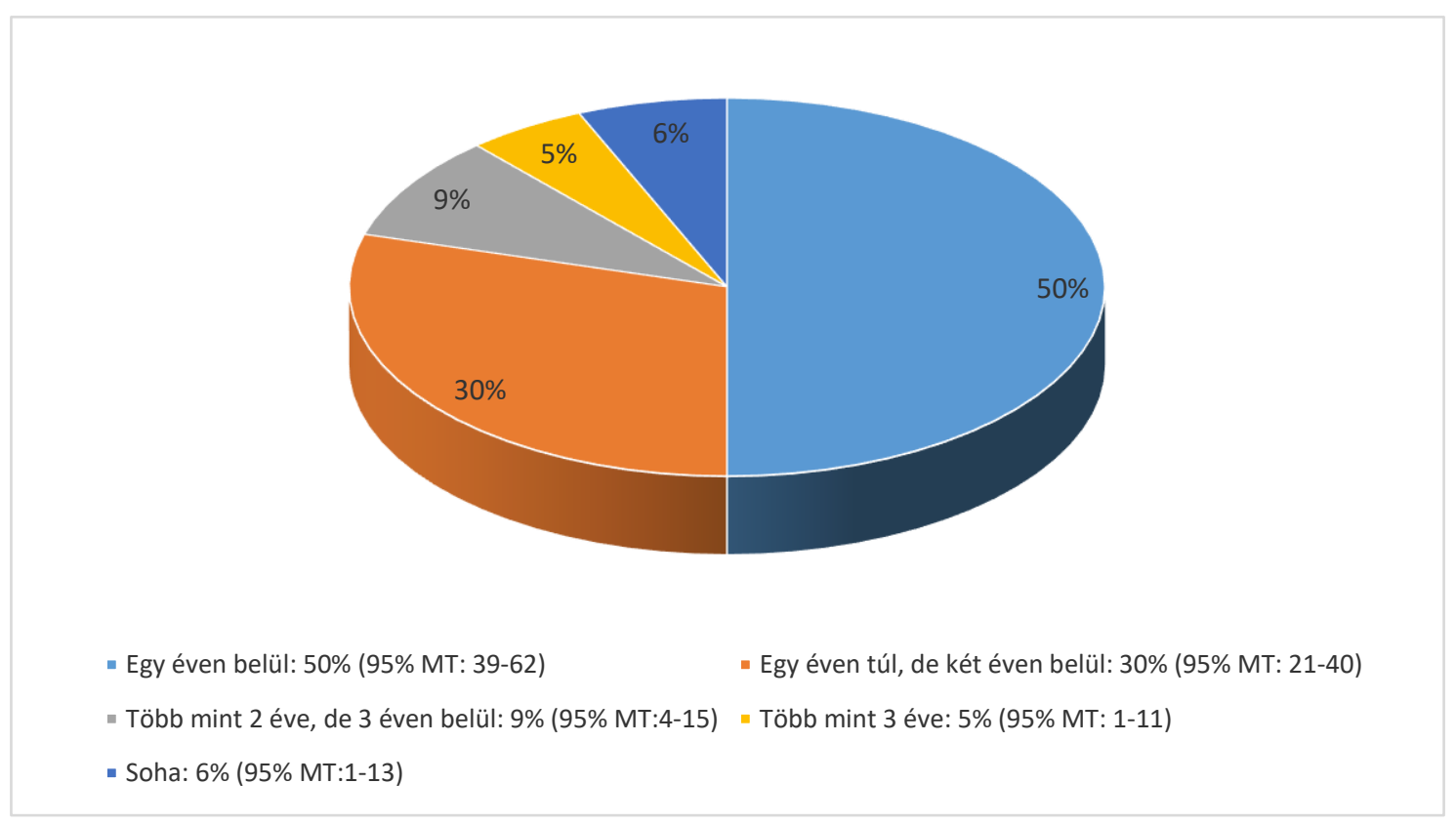

Forrás: Saját szerkesztés 
2. táblázat: Az emlőszürésen két éven belül résztvevő és a részt nem vevő 45-65 éves korú nők demográfiai és szociális jellemzői Nyíregyházán (n=84)

\begin{tabular}{|c|c|c|c|}
\hline Jellemzők & $\begin{array}{l}\text { Szürésen két éven belül } \\
\text { résztvevők }\end{array}$ & $\begin{array}{c}\text { Szürésen két éven belül } \\
\text { nem résztvevők }\end{array}$ & p-érték \\
\hline Életkor (átlag) (SD) & $44,5(1,07)$ & $51,8(2,09)$ & $\begin{array}{l}\text { Két mintás t-próba } \\
\qquad \mathrm{p}<0,001^{*}\end{array}$ \\
\hline $\begin{array}{l}\text { Iskolai végzettség } \\
\text { Alapfokú végzettség } \\
\text { Középfokú végzettség } \\
\text { Felsőfokú végzettség }\end{array}$ & $\begin{array}{l}33 \% \\
84 \% \\
79 \%\end{array}$ & $\begin{array}{l}67 \% \\
16 \% \\
21 \%\end{array}$ & $\begin{array}{l}\chi 2 \text { próba } \\
p=0,018^{*}\end{array}$ \\
\hline Foglalkoztatottság (\%) & $80 \%$ & $80 \%$ & $\begin{array}{l}x 2 \text { próba } \\
\text { p>0,05 }\end{array}$ \\
\hline $\begin{array}{l}\text { Háztartások nettó jövedelme (át- } \\
\text { lag) (SD) (forint) }\end{array}$ & 247115 (154 624) & 262500 (179 695) & $\begin{array}{l}\text { Két mintás t-próba } \\
\qquad p>0,05\end{array}$ \\
\hline $\begin{array}{l}\text { Háztartások nettó jövedelme } \\
100 \text { ezer Ft/hó alatt } \\
\text { 101-200 ezer Ft/hó } \\
\text { 201-300 ezer Ft/hó } \\
300 \text { ezer Ft/hó fölött }\end{array}$ & $\begin{array}{l}75 \% \\
82 \% \\
79 \% \\
87 \%\end{array}$ & $\begin{array}{l}25 \% \\
18 \% \\
21 \% \\
13 \%\end{array}$ & $\begin{array}{l}x 2 \text { próba } \\
\text { p>0,05 }\end{array}$ \\
\hline
\end{tabular}

Forrás: Saját szerkesztés

4. ábra: A 45-65 éves korú nők két éven belüli részvétele a mammográfián Nyíregyházán, Magyarországon, és az Európai Unió 28 országában iskolai végzettség szerint (\%)

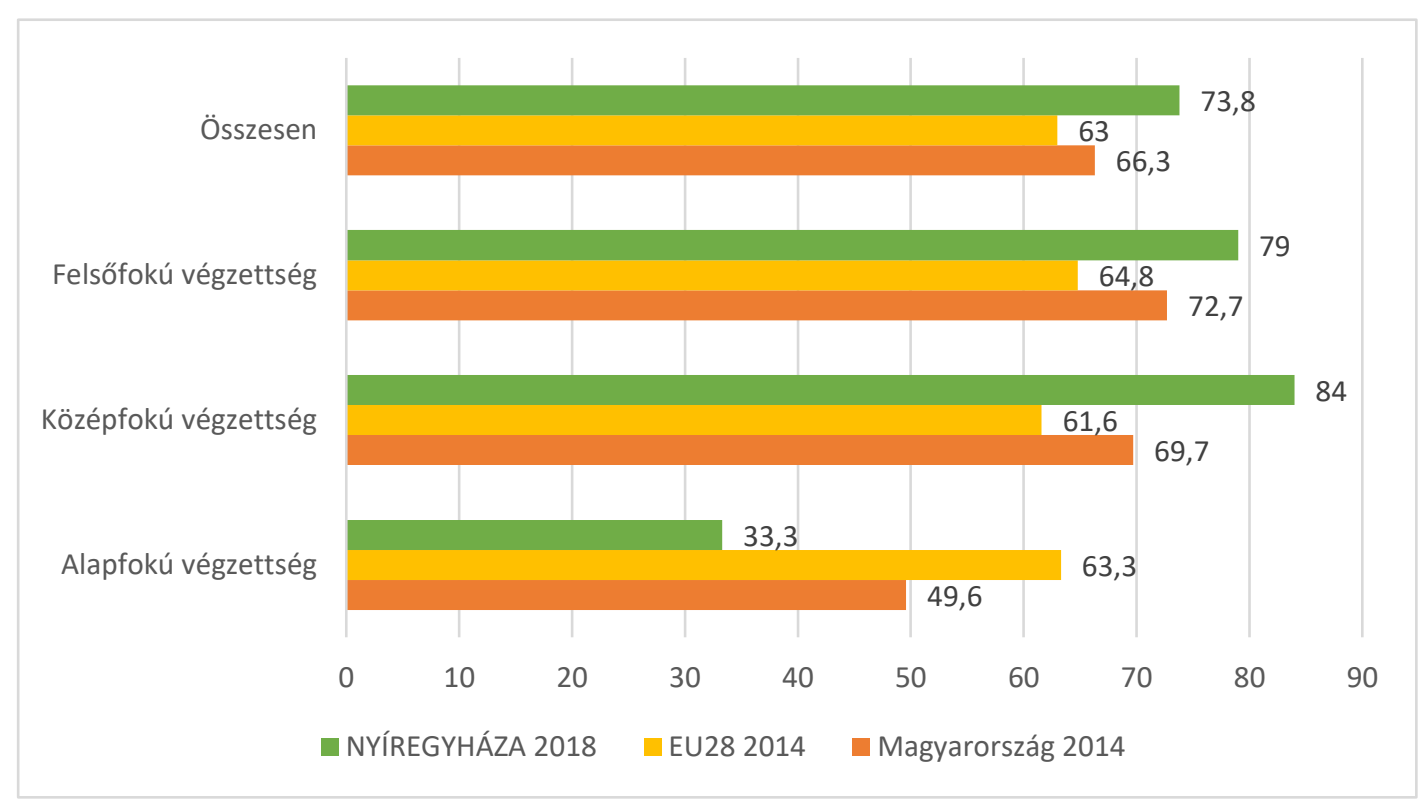

Forrás: Saját szerkesztés

\section{MEGBESZÉLÉS}

Az általunk vizsgált mintában a nyíregyházi nők átszűrtsége mindkét szúrővizsgálat esetén meghaladta az azonos módszertannal készült, önbevalláson alapuló vizsgálatok adatai alapján az európai és a magyarországi adatokat is. ${ }^{20}$
A válaszadó 25-65 éves korú nők 77\%-ától (95\% MT: 70-83) vettek kenetet citológiai vizsgálatra (szervezett szúrés keretében, vagy azon kívül) az adatfelvételt megelőző 3 éven belül (hároméves lefedettség), továbbá a mammográfia esetében a 45-65 évesek kétéves átszűrtsége (lefedettsége) 80\%-os volt. Az eredmények értelmezése során 
figyelembe kell venni az alacsony elemszám miatti kiválasztási hibát, továbbá azt, hogy a válaszadók között csupán egy fő volt, aki roma nemzetiségűnek vallotta magát. Nyíregyházán a főleg romák lakta Huszár és Keleti lakótelepeken élők körében 2018ban megvalósult vizsgálat eredményei alapján a roma nemzetiségúek körében az átszürtség alacsonyabb volt mindkét szűrővizsgálat esetében. Mammográfián a Huszár telepen élő 45-65 évesek 27\%-a soha életében nem vett részt, ez az érték a saját (nem roma nemzetiségűek körében elemzett) mintában csak $6 \%$ volt. A méhnyakszűrés vonatkozásában pedig elmondható, hogy a 25-65 éves Huszár és Keleti lakótelepen élő (főként roma nemzetiségú) nők 32,4\%-a több mint 3 éve, további $12,7 \%$-a pedig soha nem vett részt, tehát körükben a 3 éves lefedettség 55\% körüli értéket mutat. ${ }^{21}$ Összességében a magasabb átszűrtséggel kapcsolatos eredményeink megfeleltek a várakozásainknak, egyrészt azért, mert a lakosság halálozási mutatói, egészségi állapota és egészségmagatartása a megyei jogú városokban még a hátrányos helyzetú megyékben (köztük Szabolcs-Szatmár-Bereg megyében) is lényegesen kedvezőbbek, mint az országos átlag.22 Másrészt a "Nyíregyháza Életminősége Háztartáspanel" kutatás korábbi városi és vonzáskörzetéhez tartozó eredményei is azt tükrözik, hogy a nyíregyházi lakosok egészségi állapota a megye és a járás lakosságához viszonyítva lényegesen jobbnak mondható. ${ }^{23,24}$

A szűrővizsgálatokon való részvétel okainak elemzése során megállapítottuk, hogy a szervezett szűrésre történő meghívás a méhnyakszűrés esetében csupán a szúrésen résztvevők 12,5\%-a (95\% MT: 7-18) esetében szerepelt, míg az emlőszürésen résztvevő nők 57\%-a (95\% MT: 46-68) vette igénybe az ellátást a nemzeti szűrőprogram keretében kiküldött meghívólevél hatására. Ebből arra következtetünk, hogy a mintában szereplő nyíregyházi nőkre inkább az opportunisztikus szúrési gyakorlat a jellemző, különösen a méhnyakszűrés esetében, mely eredmény összhangban van számos hazai szerző elemzésének eredményeivel. ${ }^{25,26,27,28}$ A szervezett, meghíváson alapuló népesség alapú szúréssel ellentétben az opportunista szúrés az egyes nők és/vagy orvosaiknak a kezdeményezésétől függ. Ez a fajta szűrés a lakosság egy bizonyos rétegének a gyakori, vagy indokolatlan gyakorisággal végzett átvizsgálást eredményezi, míg a lakosság másik rétege, általában a hátrányos helyzetǔek körében alacsonyabb lefedettség tapasztalható. Ez a helyzet egyenlőtlen lefedettséget eredményez heterogén minőséggel, korlátozott hatékonysággal, kedvezőtlenebb költséghatékonysággal, továbbá a lakosság nyomon követésének nehézségével. ${ }^{29,30}$

Az idősebb életkor általában korlátozza a szűrővizsgálatokon való részvételt, Nyíregyházán az életkor és a szúrések igénybevétele közötti kapcsolat elemzése során azt tapasztaltuk, hogy mindkét szürővizsgálatot a fiatalabb korcsoport veszi inkább igénybe, ami a méhnyakszűrés esetén átlagosan 7 évet jelentett, a mammográfián részt vettek átlagéletkora pedig 4 évvel volt fiatalabb volt, mint azoké, akik két éven túl, vagy soha nem vették igénybe az ellátást. ${ }^{31,32}$

A társadalmi-gazdasági háttérváltozók és a szürésen való részvétel kapcsolatát vizsgálva megállapítottuk, hogy a magasabb jövedelmi kategóriába eső háztartásokban élő és gazdaságilag aktívak körében szignifikánsan magasabb a méhnyakszưrésen való részvételi hajlandóság, a mammográfia esetében pedig magasabb átszürtséggel rendelkeztek a legalább középfokú végzettséggel rendelkezők, mint a legfeljebb alapfokú végzettségúek csoportja. Ez az eredmény kulturális barrierekre utal, összhangban van más tanulmányokkal, melyek szerint az alacsonyabb társadalmi gazdasági státusz prediktora a szűrésről való távolmaradásnak. 33,34,35,36

A Nyíregyházán élő nők számára mindkét szűrővizsgálat könnyen és ingyen elérhető a SzabolcsSzatmár-Bereg Megyei Kórházak és Egyetemi Oktatókórház Jósa András Oktatókórházában, a méhnyakszúrés vonatkozásában már a helyi védőnői körzetek egy részében is biztosítottak a szúrés feltételei. A szúrési programok sikere tehát elsősorban a megfelelő lakossági részvétel (compliance) függvénye.

Felmérésünk eredményei alapján megállapítható, hogy a nyíregyházi nők emlő- és méhnyakszűrésen való részvételi arányai nem alacsonyak, ugyanakkor az alacsonyabb társadalmi-gazdasági státuszú, jellemzően idősebb korosztályba tartozó nőket nem sikerült kellő mértékben bevonni a szűrőprogramba. A szervezett szürésre történő meghívás különösen a méhnyakszúrés esetében elégtelenül múködik. Ezért a helyi szinten megvalósuló egészségfejlesztési és szürési programokban együttmüködő szakembereknek ezeket a gátló tényezőket is figyelembe kell vennie a beavatkozások tervezése során. 


\section{HIVATKOZÁSOK}

${ }^{1}$ Bray F, Ferlay J, Soerjomataram I, et al. Global cancer statistics 2018: GLOBOCAN estimates of incidence and mortality worldwide for 36 cancers in 185 countries. CA Cancer J Clin, Published online 12 September 2018; doi: 10.3322/caac.21492

${ }^{2}$ Kásler, M, Ottó, Sz, Kenessey, I. A rákmorbiditás és -mortalitás jelenlegi helyzete a Nemzeti Rákregiszter tükrében. Orv Hetil., 2017, 158(3), 84-89. doi: 10.1556/650.2017.30654

${ }^{3}$ Sárváry, A. A magyar nők rosszindulatú daganatos betegségek miatti korai halálozásának jellemzői 1980 és 2011 között. Acta Med. Soc., 2015, 6(16), 59-78.

http://ams.foh.unideb.hu/sites/ams.foh.unideb.hu/files/04 sarvary attila 03.pdf (elérve: 2019. 08. 10.)

${ }^{4}$ Országos Onkológiai Intézet. Nemzeti Rákregiszter: http://www.onkol.hu/hu/rakregiszter-statisztika (elérve: 2019. 08. 16.)

${ }^{5}$ Központi Statisztikai Hivatal. Tájékoztatási adatbázis. http://statinfo.ksh.hu/Statinfo/haDetails.jsp (elérve: 2019. 08. 16.)

${ }^{6}$ Ádány Róza (szerk.) Megelőző orvostan és népegészségtan (2. átdolgozott kiadás) Medicina, Budapest; 2012.

${ }^{7}$ Uzzoli A, Vitrai J, Bakacs M, et al. A lakóhelytől függ az esély a jobb minőségű ellátásra - Az ellátáshoz való hozzáférés területi egyenlőtlenségei Magyarországon, a szürkehályogműtétek példáján. Tér és Társadalom 2011; 25: 88-105 doi: 10.17649/TET.25.2.1815

${ }^{8}$ World Health Organization International Agency for Research on Cancer. IARC Monographs on the evaluation of carcinogenic risks to humans. Human papillomaviruses, vol. 90. Lyon: IARC Press; 2007.

${ }^{9}$ Quinn M, Babb P, Jones J, et al. Effect of screening on incidence of and mortality from cancer of cervix in England: evaluation based on routinely collected statistics. BMJ. 1999 318(7188):904-8. doi: 10.1136/bmj.318.7188.904

${ }^{10}$ Miller AB, World Health Organization Cervical cancer screening programmes. Managerial guidelines. Geneva: World Health Organization; 1993. https://apps.who.int/iris/handle/10665/39478 (elérve: 2019.08.10.)

${ }^{11}$ Arbyn M, Raifu AO, Weiderpass E, et al. Trends of cervical cancer mortality in the member states of the European Union. Eur J Cancer. 2009 Oct;45(15):2640-8. doi: 10.1016/j.ejca.2009.07.018

${ }^{12}$ Laara E, Day NE, Hakama M. Trends in mortality from cervical cancer in the Nordic countries: association with organised screening programmes. Lancet 1987;1:1247-9. doi: 10.1016/s0140-6736(87)92695-x

13 Bray F, Loos AH, McCarron P, et al. Trends in cervical squamous cell carcinoma incidence in 13 European countries: changing risk and the effects of screening. Cancer Epidemiol Biomarkers Prev 2005;14:677-86.

doi: 10.1158/1055-9965.EPI-04-0569

${ }^{14}$ Shapiro S, Venet W, Strax P, et al. Selection, follow-up, and analysis in the Health Insurance Plan Study: a randomized trial with breast cancer screening. Natl Cancer Inst Monogr 67:65-74, 1985

https://europepmc.org/abstract/med/4047153 (elérve: 2019. 09.10.)

15 Tabár L, Fagerberg CJ, Gad A, et al. Reduction in mortality from breast cancer after mass screening with mammography. Randomised trial from the breast cancer screening working group of the Swedish National Board of Health and Welfare. Lancet 1:829-832, 1985 doi: 10.1016/s0140-6736(85)92204-4

${ }^{16}$ Council of the European Union. Council Recommendation of 2 December 2003 on Cancer Screening (2003/878/EC). OJ L 327: 34-3. https://ec.europa.eu/jrc/sites/jrcsh/files/2_December_2003\%20cancer\%20screening.pdf (elérve: 2019.09.10.)

17 Egészséges Nemzetért Népegészségügyi Program 2001-2010. Egészségügyi Közlöny 2001/16. szám. 2001. augusztus 21.

18 46/2003. (IV. 16.) OGY-határozat az Egészség Évtizedének Johan Béla Nemzeti Programjáról.

https://mkogy.jogtar.hu/jogszabaly?docid=a03h0046.0GY (elérve: 2019. 09. 01.)

${ }^{19}$ SPSS Statistical Package for the Social Sciences v. 22.0 IBM Corp., Armonk, NY, USA

${ }^{20}$ European Statistical Office. Healthcare activities statistics - preventive services

https://ec.europa.eu/eurostat/statistics-explained/index.php?title=Healthcare activities statistics preventive services\#Cervical cancer screening (elérve: 2019.09. 01.)

${ }^{21}$ Jávorné Erdei R, Takács P. A Huszár- és Keleti lakótelepeken élők egészségi állapota Nyíregyházán - életminőségre gyakorolt hatások. Acta Med. Soc. 2019; Megjelenés alatt

22 Ádány R. A magyar lakosság egészségi állapota, különös tekintettel az ezredforduló utáni időszakra.

Népegészségügy. 2009; 86:2.: 5-20.

${ }^{23}$ Hüse L. A szubjektív egészségi állapot tényezői és azok változása Nyíregyházán és vonzáskörzetében.

Acta Med. Soc. 2015; Vol.6. No.18-19. p. 96-120. doi: 10.19055/ams.2015.6/18-19/7

http://epa.oszk.hu/02500/02535/00013/pdf/EPA02535 acta med 2015 18-19 096-120.pdf (elérve: 2019.09.01.) 
24 Jávorné Erdei R. Takács P. Szubjektív egészségi állapot és annak változásai Nyíregyházán. Acta Med. Soc. 2018; Vol. 9. No. 27. (96-109) doi: 10.19055/ams.2018.9/27/7

http://epa.oszk.hu/02500/02535/00020/pdf/EPA02535 acta med 201827 096-109.pdf (elérve: 2019.09.01.)

${ }^{25}$ Döbrőssy L, Kovács A, Döbrőssy B, et al. Miért kihasználatlan hazánkban a szervezett lakosságszúrés? LAM 2010; 20: 689-693. http://www.elitmed.hu/upload/pdf/miert kihasznalatlan hazankban a szervezett lakossagszures-6335.pdf (elérve: 2019.09.01.)

${ }^{26}$ Kovács A, Döbrőssy L, Budai A, et al. A népegészségügyi méhnyakszűrés helyzete Magyarországon 2006-ban. Orv Hetil. 2007;148:535-540. doi: 10.1556/OH.2007.28019

27 Boncz I, Sebestyén A, Döbrőssy L, et al. A méhnyakszúrés részvételi mutatói Magyarországon. Orv Hetil. 2007;148(46), 2177-2182. doi: 10.1556/OH.2007.28956

${ }^{28}$ Kovács A, Boncz I. A szekunder prevenciós onkológiai szúrési programok helyzete Magyarországon. Népegészségügy 2009;87:265-275.

${ }^{29}$ Arbyn M, Anttila A, Jordan J, et al. European Guidelines for Quality Assurance in Cervical Cancer Screening. Second Edition-Summary Document. Ann. Oncol. 2010; 21:448-458. doi: 10.1093/annonc/mdp4

${ }^{30}$ Priaulx J, de Koning HJ , de Kok IMCM, et al. Identifying the barriers to effective breast, cervical and colorectal cancer screening in thirty one European countries using the Barriers to Effective Screening Tool (BEST). Health Policy 2018;

(122) 11:1190-1197. doi:10.1016/j.healthpol.2018.08.004

${ }^{31}$ Seidel D, Becker N, Rohrmann S, et al. Socio-demographic characteristics of participation in the opportunistic German cervical cancer screening programme: results from the EPIC-Heidelberg cohort. J Cancer Res Clin Oncol. 2009;

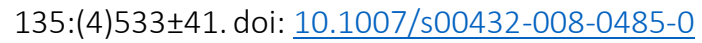

${ }^{32}$ Kristensson JH, Sander BB, von Euler-Chelpin M, et al. Predictors of non-participation in cervical screening in Denmark. Cancer Epidemiol. 2014; 38:(2)174 \pm 80 . doi: 10.1016/j.canep.2013.12.007

${ }^{33}$ Gyulai A, Nagy A, Pataki V, et al. Survey of Participation in Organised Cervical Cancer-Screening Programme in Hungary. Cent Eur J Public Health 2015; 23 (4): 360-364. doi: 10.21101/cejph.a4068

${ }^{34}$ Kristensson JH, Sander BB, von Euler-Chelpin M, et al. Predictors of non-participation in cervical screening in

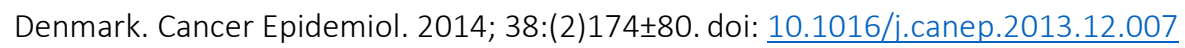

${ }^{35}$ Virtanen A, Nieminen P, Luostarinen T, et al. Self-sample HPV tests as an intervention for nonattendees of cervical

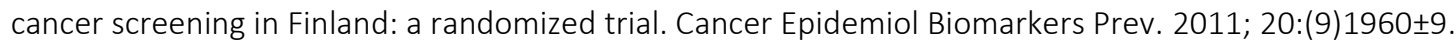

doi: 10.1158/1055-9965.EPI-11-0307

${ }^{36}$ Gok M, Heideman DA, van Kemenade FJ, et al. HPV testing on self collected cervicovaginal lavage specimens as screening method for women who do not attend cervical screening: cohort study. BMJ. 2010; 340c1040.

doi: $10.1136 /$ bmj.c1040 